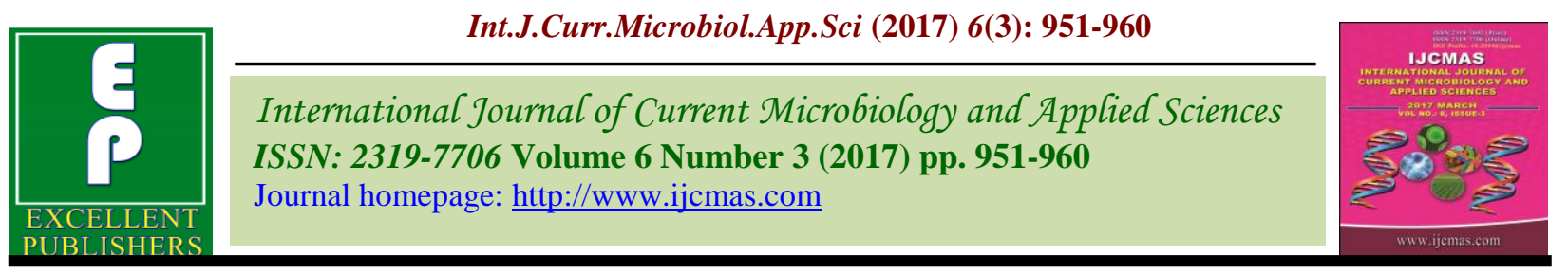

Original Research Article

https://doi.org/10.20546/ijcmas.2017.603.113

\title{
Exploring Rapid and Efficient Protocol for Isolation of Fungal DNA
}

\author{
Swapan K. Tripathy*, Manasmita Maharana, Dinesh Manohar Ithape, \\ Devraj Lenka, Dayanidhi Mishra, Arjun Prusti, Digbijaya Swain, \\ Mihir Ranjan Mohanty and K.R. Reshmi Raj
}

Department of Agricultural Biotechnology, College of Agriculture, OUAT, Bhubaneswar-751003, India

*Corresponding author

\begin{tabular}{|c|c|}
\hline & A B S T R A C T \\
\hline \multicolumn{2}{|l|}{ Keywords } \\
\hline $\begin{array}{l}\text { Deoxyribonucleic } \\
\text { acid (DNA), Rapid } \\
\text { and efficient, } \\
\text { Extraction protocol, } \\
\text { Fungi. }\end{array}$ & \multirow{3}{*}{$\begin{array}{l}\text { A simple, rapid, safe and cost effective DNA extraction method is an all } \\
\text { time need for efficient molecular screening of fungus using polymerase } \\
\text { chain reaction (PCR). A number of protocols are now available to suit } \\
\text { recovery of DNA from different fungi. But, only a few are universally used } \\
\text { for all fungal origin. In this pursuit, the authors presented a detailed review } \\
\text { of the status of fungal DNA isolation using different methods. }\end{array}$} \\
\hline Article Info & \\
\hline $\begin{array}{l}\text { Accepted: } \\
\text { 18 February } 2017 \\
\text { Available Online: } \\
10 \text { March } 2017\end{array}$ & \\
\hline
\end{tabular}

\section{Introduction}

Rapid and reliable detection of pathogenic organisms is a basic requirement for diagnosis of food-borne illness and diseases. The detection of fungal pathogens in clinical and plant samples by PCR requires an efficient method of DNA extraction. A variety of extraction protocol is available for isolation of DNA. No single extraction method seems to be optimal for all organisms (Bolano et al., 2001). Fungus may form mycellial growth (filamentous) or spores on the media depending upon the strain used. The fungus is freeze dried or lyophilized before isolation. Fungal nucleases and high polysaccharide content (mannan, $\beta$-glucans and chitin) in rigid cell wall (Chaffin et al., 1998) add to the difficulties in isolating DNA from filamentous fungi (Muller et al., 1998; Fredricks et al., 2005). Therefore, additional lysis steps, such as mechanical disruption or sonication, enzymatic digestion or use of toxic chemicals are required (Alaey et al., 2005). The CTAB extraction method was originally developed by Doyle and Doyle in 1987 for plant tissue extraction. It was considered superior for removing carbohydrates but it is timeconsuming and labor-intensive and does not result DNA yields satisfactorily from all biological samples including fungal mycelia and spores. A variety of modified CTAB methods are now available (Saghai-Maroof $e t$ al., 1984) for extraction and purification of fungal DNA using organic solvents (Blin and Stafford, 1976). Besides, several DNA 
extraction methods have been designed that include use of liquid nitrogen combined with lysis buffer, enzymatic lysis method, use of SDS or proteinase K, lysozyme (Flamm et al. 1984a,b; Wilson, 1990), high speed cell disruption (Muller et al., 1998) and beadvortexing with SDS lysis (Sambrook and Russel, 2001). Additionally, although some methods do not involve maceration in liquid nitrogen, they are still time consuming and require special columns (Noor Adila et al., 2007). Other factors for modification often adopted to minimize the time, avoid the use of expensive and hazardous chemicals, maximize the DNA yield and amenability for use in various downstream enzymatic applications, such as PCR amplification, restriction digestion, southern blotting and DNA sequencing. This may be achieved by agitating the fungal samples using sonication (ultrasound disruption: $>20-30 \mathrm{kHz}$ ) and microwave thermal shock (heat shock: 600700watt).

Plating methods are aminable for detection of fungi. Now-a-days, such age-old methods have been replaced by more rapid and sensitive techniques, such as Fluorescence InSitu Hybridization (FISH) (Chattopadhyay et al., 2013), Enzyme Linked Immuno-Sorbent Assays (ELISA) (Naravaneni and Jamil, 2005), Polymerase Chain Reaction (PCR) (Jaykus, 2003), and Real-Time PCR (RTPCR) (Wolffs et al., 2004). However, the polymerase chain reaction (PCR) is increasingly being used for identification (nucleic acid detection) and characterization of microbial communities in various environmental samples including air, soils, landfills, waters etc. PCR-based molecular marker techniques made it possible to elucidate the principles or factors underlying molecular evolution, population genetics, plant fungus interactions, or pathogen evolution at molecular level (Milgroom and Fry, 1997).

\section{Role of chemicals used for fungal DNA extraction}

Extraction of DNA requires homogenization of the fungi (mycelium/conidia/spores) and separation of DNA from rest of the biomolecules. Different chemicals used for the purpose are-

TRIS (hydroxymethyl aminomethane, Mol. wt.121.14g): It is a very strong base and also available complexes with $\mathrm{HCl}$ to form Tris$\mathrm{HCl}$ (Mol. wt. 157.56g). Tris binds with lipopolysaccharides (in the cell outer membrane). Thereby it helps to permealize the membrane and maintains a constant $\mathrm{pH}$ in the solution.

CTAB (N-Cetyl-N, N, N-trimethyl ammonium bromide, Mol. wt. 364.46g): This is a cationic detergent that simultaneously degrades and solubilizes the plant cell wall and lipid membranes of internal organelles and denatures proteins (enzymes). Besides, it dissociates complex polysaccharides and secondary metabolites like polyphenols from DNA. CTAB is probably the only compound that can separate partial nucleic acids from polyphenols. Removal of polysaccharides is badly necessary for proper restriction digestion of DNA.

EDTA (Ethylenediamine tetraacetic acid, Mol. wt. 372.2g): It prevents DNA from degradation by chelating magnesium ions needed for enzymes that degrade DNA. Urea and EDTA (bind with $\mathrm{Mg}^{+2}$ ) is used to chelate $\mathrm{Mg}^{+2}$ (a co-factor of DNase) and thereby restrict cellular DNase activity.

Sodium chloride (Mol. wt. 58.44g): DNA is negatively charged. Negatively charged phosphates tend to repel each other. $\mathrm{NaCl}$ provides $\mathrm{Na}^{+}$ions that will neutralize the negative charge of phosphates in DNA and allow the DNA molecules to come together. 
B-ME $\quad(\beta$-mercaptoethanol: $\quad \beta$ mercaptoethanol is a strong reducing agent which can remove polyphenols in the crude fungal extract. Besides, being basically a reducing agent, it breaks the disulphide bonds in protein and hence helps to separate the protein component from DNA.

PVP (Polyvinyl pyrroledone): PVP removes phenolic contaminations by forming hydrogen bonds with them. Browning of the DNA sample is checked as addition of PVP prevents oxidation phenolic compounds.

Potassium acetate (Mol. wt. 98.14g): Potassium acetate sometimes added prior to centrifugation or even added to the supernatant after centrifugation to precipitate most of the proteins and polysaccharides (if any) in form of insoluble potassium dodecyl sulphate. Incubate the contents for $20 \mathrm{~min}$. at $0^{\circ} \mathrm{C}$ in ice box for chelating. This step may be avoided if intended for proteinase $\mathrm{K}$ or $\mathrm{Na}$ acetate treatment (for removal of protein) during the purification of DNA step.

Phenol: Phenol is an effective purifier of nucleic acids owing to its non-polarity and higher density $\left(1.07 \mathrm{~g} / \mathrm{cm}^{3}\right)$ than water $\left(1.0 \mathrm{~g} / \mathrm{cm}^{3}\right)$. Phenol does not interact with DNA (polar). When phenol is added to the cell homogenate, it further breaks down superfluous cell materials that would otherwise contaminate the DNA sample. Following centrifugation, water (acquous phase at top) and phenol (organic phase at bottom) remain separate in the solution owing to differential density. DNA being polar in nature, it is dissolved in water (acquous phase) and thereby separated from organic debries settled at bottom. Clear supernatant following centrifugation is indicative of low phenolics.

Chloroform: It disrupts the bonds that hold the cell membranes by dissolving proteins, lipids, and then form complexes to precipitate out of the acquous solution. Thus, it solubilizes lipids and a lot of proteins to remove them from the DNA. Chloroform and water will separate into two distinct phases. The lower phase will be Chloroform, while DNA is present in the upper acquous phase.

Isoamyl alcohol: Iso-amyl alcohol helps to reduce foaming during extraction as well as helps to separate the aqueous phase from the organic phase by forming a thin separating layer.

Isopropanol and ethanol: DNA molecules in solution are surrounded by water molecules (shell of hydration). Ethyl alcohol and isopropanol are dehydrating agents which result disruption of hydration shell and thereby precipitate the DNA. Pre-chilled isopropanol offers better precipitation of DNA than ethanol at lesser concentration. 0.6 volume of isopropanol is sufficient for the purpose as against 2 times required in case of ethanol, but the DNA yield is more in the later. Low temperature slows down enzymes that can break down DNA, thus resulting better extraction results.

Deionized water: Deionized water is used to get rid of ions which can interfere with the extraction and follow up PCR and other molecular analysis.

\section{Fungal DNA extraction methods}

Isolation of fungal DNA is a multi-step method. It includes growing the fungus in liquid or solid medium, lyophilizing the fungal samples, disrupting cell wall, removing proteins with phenol and chloroform, and precipitating DNA with ethanol or isopropanol. Several modified methods have been designed by a number of researchers. Several workers compared different methods for ease in degradation/lysis of cell wall and 
organelle membranes. Liquid nitrogen is most commonly used for homogenization ( $\mathrm{Wu}$ et al., 2001). Some researchers used dry ice (Griffin et al., 2002), SDS lysis (Syn and Swarup, 2000), high-speed cell disruption (Muller et al., 1998) and glass bead/magnetic bead-vortexing/SDS lysis (Sambrook and Russel, 2001; Faggi et al., 2005), lysozyme lysis/enzyme digestion (Flamm et al., 1984a,b; Li et al., 2002), benzyl chloride lysis (Xue et al., 2006), sonication (Sharma et al., 2007), microwave exposure (Goodwin and Lee, 1993) and combinations of different methods (Zhang et al., 2008). In each method, the major objective lies with elimination of PCR inhibitors (metallic cations, polysaccharide, polyphenols, and other secondary metabolites) in DNA samples which would otherwise prevent DNA amplification. Besides, any protocol to be efficient for isolation of DNA relies on the ideal ratio of biological material to chemical reagents used. The usual methods of DNA extraction from filamentous fungi are either time-consuming and require toxic chemicals or are based on expensive technologies (Cheng and Jiang, 2006).

Standard CTAB method: Doyle and Doyle (1987) were successful for DNA isolation from small quantities of fresh leaf tissue using CTAB (a detergent). Since then isolation of DNA was made possible from different biological entities including fungus. Lee et al., (1988) and Wu et al., (2001) and Zhang et al., (2010) extracted DNA from filamentous fungus using standard CTAB method. Using this protocol, cell walls of fungal mycelia are broken down by grinding with glass rods, or mortar and pestle in presence of liquid nitrogen. The CTAB extraction buffer is then added followed by incubation at $65^{\circ} \mathrm{C}$, purification with phenol: chloroform: isoamyl alcohol (25: 24: 1) and precipitation with isopropanol (Ashktorab and Cohen, 1992). Finally, the DNA is dissolved in $50 \mu l$ of pure water or TE buffer.
SDS method: Prabha et al., (2013) recovered DNA from water moulds using extraction buffer containing 200mM Tris- $\mathrm{HCl}, \mathrm{pH} 7.5$; $25 \mathrm{mM}$ EDTA and $250 \mathrm{mM} \mathrm{NaCl}$ and $0.5 \%$ SDS. The protocol takes relatively less time without the need to employ $\beta$ mercaptoethanol, CTAB, lysozyme digestion, proteinase $\mathrm{K}$ treatment etc. and thereby reducing the overall costs involved. González-Mendoza et al., (2010) attempted minipreparation of DNA from a sample size of $10 \mathrm{mg}$ of each fungal mycelium using $0.2 \mathrm{ml}$ extraction buffer $(3 \%$ SDS, $0.5 \mathrm{mM}$ EDTA, $1.0 \mathrm{M} \mathrm{NaCl}$, and $0.1 \mathrm{mM}$ Tris- $\mathrm{HCl}, \mathrm{pH} 8.0$ followed by addition of $0.2 \mathrm{ml}$ chloroformphenol mix and incubation at $65^{\circ} \mathrm{C}$ for $5 \mathrm{~min}$. The mixture was cooled to room temperature and centrifuged at $10,000 \mathrm{~g}$ at $4^{\circ} \mathrm{C}$ for $5 \mathrm{~min}$. The supernatant was transferred to a fresh appendorf tube, and an equal volume of cold absolute isopropanol or ethanol was added and the contents mixed thoroughly for precipitating total DNA at $-20^{\circ} \mathrm{C}$ for $20 \mathrm{~min}$.

Combined CTAB and SDS method: Umesha et al., (2016) used an improved method for DNA isolation by combining CTAB with SDS method without addition of Proteinase $\mathrm{K}$, RNase $\mathrm{K}$ and $\beta$-mercaptoethanol. This was reported to be better and rapid than CTAB, SDS and microwave method for isolation of genomic DNA from food-borne fungal pathogens. $200 \mathrm{mg}$ of lyophilized mycelial powder added with $500 \mu l$ extraction buffer (250mM Tris- $\mathrm{HCl} \mathrm{pH} 8.0,20 \mathrm{mM}$ EDTA pH 8.0, 200M NaCl, 10\% CTAB, 0.15\% SDS) was vortexed and then boiled for $10 \mathrm{~min}$ at $50^{\circ} \mathrm{C}$ followed by centrifugation at $10,000 \mathrm{rpm}$ for $10 \mathrm{~min}$. The upper supernatant was pipetted out and mixed with one volume of chloroform: isoamyl alcohol (23:2) and centrifuged at $10,000 \mathrm{rpm}$ for $5 \mathrm{~min}$. The aqueous phase was recovered and mixed with one volume of ice cold isopropanol to precipitate DNA. 
Urea/Chelex/SDS method: DNA isolation from Cryptococcus neoformans is difficult due to a thick and resistant capsule. Mseddi et al., (2011) have optimized a new and rapid DNA isolation method for $C$. neoformans using a short urea treatment followed by a rapid method using a chelex resin suspension (10\% Chelex 100, 0.1\% SDS, $1 \%$ Nonidet P 40 , and $1 \%$ Tween 80 ). The samples were incubated at $95^{\circ} \mathrm{C}$ for $30 \mathrm{~min}$ and then on ice for $5 \mathrm{~min}$. DNA was removed from the supernatant after $5 \mathrm{~min}$ of centrifugation $(10,000 \mathrm{rpm})$ and stored at $-20^{\circ} \mathrm{C}$ until used.

Glass beads method: Although PCR amplification can be performed directly on various microbial cultures, for filamentous fungi and yeast, prior isolation of DNA is often preferred. Standard methods are available that eliminates many interfering substances like mineral salts, proteins, polysaccharides, and plays an important role in ensuring consistent results. But, such method is laborious, expensive and time consuming (Van Burik et al., 1998). Therefore, some workers used glass beads as a substitute to liquid nitrogen. Gontia-Mishra et al., (2014) employed glass bead method for disruption of filamentous fungal cell walls in an extraction buffer $(0.1 \mathrm{M}$ Tris- $\mathrm{HCl} \mathrm{pH} 8.0$, $10 \mathrm{mM}$ EDTA $\mathrm{pH} 8.0,2.5 \mathrm{M} \mathrm{NaCl}, 3.5 \%$ CTAB) followed by inactivation of proteins using $150 \mu \mathrm{l}$ of $20 \mathrm{mg} / \mathrm{ml}$ Proteinase K. The DNA yield from fungal isolates (Aspergillus niger, A. flavus, A. awamori, A. fumigatus, A. ficuum and $A$. terreus) varied from 310$1879 \mu \mathrm{g} / \mathrm{g}$ dry mycelium and a clear intact DNA band was observed upon agarose gel electrophoresis. Aamir et al., (2015) also used glass beads for homogenizing mycelium in lysis buffer $(100 \mathrm{mM}$ Tris- $\mathrm{HCl} \mathrm{pH} 8.0,50 \mathrm{mM}$ EDTA, 3\%SDS). Plaza et al., (2004) used $200-500 \mathrm{mg}$ fungal mycelium to add with $500 \mu 1$ extraction buffer solution (in a $1.5 \mathrm{ml}$ micro centrifuge tubes) containing: $0.1 \mathrm{M}$ $\mathrm{NaCl}, 0.5 \mathrm{M}$ Tris- $\mathrm{HCl} \mathrm{pH} 8.0$ and $5 \%$ SDS.
The contents are ground 10 min. using glass beads followed by centrifugation at $11,000 \mathrm{~g}$ for 10min., precipitation of DNA in the supernatant by isopropanol and washing of DNA pellets using $70 \%$ ethyl alcohol. The protocol can be applied to filamentous fungi from soil as well as from other environmental sources.

Lysis buffer method: Most of the methods rely on using a grinder (with or without liquid nitrogen) for homogenization. Zhang et al., (2010) developed a simple and rapid method for isolation of DNA from different fungal isolates. In this context, the fungal mycelia or yeast cells were first rinsed with pure water to remove potential PCR inhibitors followed by thermolysis at $85^{\circ} \mathrm{C}$ in a lysis buffer $(50 \mathrm{mM}$ sodium phosphate at $\mathrm{pH} 7.4,1 \mathrm{mM}$ EDTA and $5 \%$ glycerol) to break down cell walls and membranes. High as well as single-copy number genes were successfully amplified from the extracted DNA samples. The DNA samples obtained by this method can be stored at $20^{\circ} \mathrm{C}$ for over 1 year. Besides, Liu et al., (2000) used a lysis buffer containing $400 \mathrm{mM}$ Tris-HCl pH 8.0, 60mM EDTA $\mathrm{pH}$ 8.0, $150 \mathrm{mM} \mathrm{NaCl}, 1 \%$ SDS followed by addition of $5 \mathrm{M}$ Potassium acetate for extraction of DNA from filamentous fungi.

Microwave method: Microwave radiation has been shown to be effective in killing Magnaporthe grisea (rice blast fungus). Genomic DNA may be isolated from as little as $2 \mathrm{mg}$ dry biomass of such filamentous fungus by microwave radiation treatment within 30s (Tendulkar et al., 2003). The Fungal biomass $(2 \mathrm{mg})$ was washed and suspended in $50 \mu \mathrm{l}$ of $\mathrm{TE}(10 \mathrm{mM}$ Tris $/ \mathrm{HCl}$ buffer, $\mathrm{pH}$ 8.0, $100 \mathrm{mM}$ EDTA $\mathrm{pH}$ 8.0) in microcentrifuge tubes followed by microwave treatment at $2450 \mathrm{MHz}$ frequency in a microwave oven of $230 \mathrm{~V}$ output at $28^{\circ} \mathrm{C}$ for $30 \mathrm{~s}$. The treated biomass was incubated at $28^{\circ} \mathrm{C}$ for $5 \mathrm{~min}$ and centrifuged at $10,000 \mathrm{~g}$ for 
5min. The supernatant contained genomic DNA and was used directly for PCR as well as for dot blot hybridization. This method avoids the use of hazardous chemicals like CTAB, SDS, $\beta$-mercaptoethanol, phenol, chloroform and isoamyl alcohol. This technique has been also suitably used along with chitinase treatment in case of filamentous fungi, like Aspergillus (Bir et al., 1995). The quantity of DNA was good enough for PCR analysis and Dot blot hybridization. Further, genomic DNA yield as high as $9091 \mathrm{ng} / \mu \mathrm{l}$ can be extracted from $5 \mathrm{mg}$ of 3-4 day old fungal mycelium, Fusarium, Verticillium, Bipolaris oryzae, Rhizoctonia solani by combined lysis buffer-microwave treatment. The method seems to be quite simple, cost effective, rapid and efficient for PCR assay of specific gene tagging.

Sonification method: The ultra sonic waves can easily destroy the cell wall (Voget et al., 2003, Sharma et al., 2007). However, it is less used for extraction of DNA than other cellular components such as proteins and pigments. Sonication is a very efficient and reliable tool that allows a complete control over different parameters. This ensures a high selectivity on materials release and product purity. It is a quite versatile method suitable to all cell types and easily applicable in small and large scale (Kennedy and Marchesi, 2007). Lysis of mycelia can be achieved by sonication for $40 \mathrm{~min}$. at $55^{\circ} \mathrm{C}$ in a Bransen 2200 waterbath sonicator (Van Burik et al., 1998).

Enzymetic lysis method: Lysozyme alone or in combination with SDS is in vogue used for lysis of fungal cell walls (Flamm et al., 1984a,b). An extraction method based on enzymatic lysis produced high levels of fungal DNA with Candida albicans (a model filamentous fungal pathogen) but low levels of fungal DNA with Aspergillus fumigatus conidia or hyphae (a model yeast pathogen) as revealed from qPCR (Fredricks et al., 2005).
Purohit and Singh (2009) included lysozyme in the lysis buffer for extraction of metagenomic DNA of microbes living in saline habitat.

Universal method: A single protocol universally used for plant, algae, blood, bacteria, fungus will be more demanding (Kumar et al., 2012) than those suited specific to a particular biological material. The extraction buffer used in this case included $100 \mathrm{mM}$ Tris- $\mathrm{HCl}, \mathrm{pH} 8.0,25 \mathrm{mM}$ EDTA, $1.5 \mathrm{M} \mathrm{NaCl}, 2 \%$ CTAB, $\beta$-mercaptoethanol, PVP(in case of plant sample). The method utilizes the classical protocol for homogenization by liquid nitrogen, incubation in water bath at $65^{\circ} \mathrm{C}$, deproteinization by chloroform-isoamyl alcohol followed by ethanol precipitation and washing. Alternative to the above, other universal methods termed as 'nuclei method' and 'protoplast method' may be successfully used to prepare highquality megabase-sized DNA (Zhang et al., 2012). In this method, nuclei are first isolated by physically grinding the source tissues. The protoplast method uses the cell wall hydrolases such as cellulose and pectinase to remove the cell walls of plants, algae, fungi, bacteria and yeast before isolating DNA. In case of 'nuclei method', nontarget cytoplast organellar genomes and other cytoplsmic organelles and cytosolic metabolites are removed by centrifugation and washing, thus maximizing the utility of the method and substantially improving the digestibility and clonability of the resultant DNA.

Rapid and a direct method: Jia et al., (2014) designed a rapid and direct method that avoid precipitation step. They extracted DNA from stored desiccated (at $-20^{\circ} \mathrm{C}$ ) fungus grown on a piece of filter paper $(0.5-1.0 \mathrm{~cm}$ diameter $)$. The fungal sample was placed in a $0.2 \mathrm{ml}$ Eppendorf tube containing $100 \mu \mathrm{l} 10 \mathrm{x}$ TE. The suspension was heated for $10 \mathrm{~min}$ at $95{ }^{\circ} \mathrm{C}$ in a PCR machine. The tube was then 
centrifuged for $1 \mathrm{~min}$ at $3000 \mathrm{rpm}$. One $\mu \mathrm{l}$ of 10x TE solution containing DNA can be suitably used for PCR amplification. The DNA prepared directly from the fungus on filter paper appeared suitable for a rapid survey of genetic identity of the rice blast fungus. The protocol proved to be the most safe, quickest and cost-effective method that took just $11 \mathrm{~min}$. to complete the process without use of any costly and hazardous chemicals.

\section{Checking for quantity and quality of fungal DNA}

The PCR technique requires sufficient quantity and high quality DNA of pathogens. Success in development of a DNA isolation protocol needs to be verified by status of DNA in terms of quality and quantity of DNA. Concentration of DNA (ng/ $\mu \mathrm{l})$ samples was determined by spectrophotometry at 260 $\mathrm{nm}$ wave length, and the purity is assessed as $\mathrm{OD}_{260} / \mathrm{OD}_{280}$ using UV-VIS spectrophotometer or NanoDrop (Thermo Electron Scientific Instruments LLC, USA). Further, the DNA quality may be assessed by electrophoresis following PCR amplification of genomic DNA using gene specific primers.

\section{Precautions}

Every precaution must be taken to avoid the laboratory borne contamination during DNA extraction. To make contamination free, the needle/loop needs to be flame sterilized. The bottles and culture tubes may be treated with $0.1 \%$ diethyl pyrocarbonate (DEPC) solution at $37^{\circ} \mathrm{C}$ overnight, autoclaved twice at $121^{\circ} \mathrm{C}$ for $20 \mathrm{~min}$, and then dried at $100^{\circ} \mathrm{C}$ before use. Tips used for DNA extraction are required to be DNase-and RNase-free, while pipettes/Petri plates need steam sterilized before working. Besides, use of gloves and safety glasses are must as most of the protocols involve hazardous chemicals.
It can be concluded that the plants at different stages are suffered from a number of pathogenic fungi. Certain food and food products serve as high-risk substrate for growth of fungi. Besides, human health is threatened by notorious fungal infections. Now-a-days, PCR has become a common tool for detection, identification and characterization of microbial clinical samples. Besides, PCR and advanced molecular analysis made it possible to study gene expression, cloning of genes, elucidation of factors underlying fungal evolution, population genetics, plant-fungus interactions. These demand a rapid and efficient protocol for isolation of pure fungal DNA. Several protocols are now available for this purpose but no single extraction method seems to be optimal for all fungal entities.

\section{Acknowledgement}

We sincerely acknowledge and thank all researchers for their valuable contributions included in this pursuit.

\section{References}

Aamir, S., Sutar, S., Singh, S.K., Baghela, A. 2015. A rapid and efficient method of fungal genomic DNA extraction suitable for PCR based molecular methods, Plant Pathol. Quarantine, 5(2): 74-81.

Ashktorab, H. and Cohen, R.J. 1992. Facile isolation of genomic DNA from filamentous fungi. BioTechniques, 13: 198-200.

Alaey, M., Naderi, R., Vezvaei, A., Khalighi, A. 2005. Comparing study between four different methods of genomic DNA extraction from Cyclamen persicum Mill. Int. J. Agric. Biol., 7: 882-884.

Bir, N., Paliwal, A., Muralidhar, K., Reddy, P., Sarma, P.U. 1995. A rapid method for the isolation of genomic DNA from 
Aspergillus fumigatus. Prep. Biochem., 25: 171-181.

Blin, N. and Stafford, D.W. 1976. Isolation of high molecular weight DNA. Nucleic Acids Res., 3: 2303-2308.

Bolano, A., Stinchi, S., Preziosi, R., Bistoni, F. 2001. Rapid methods to extract DNA and RNA from Cryptococcus neoformans. FEMS Yeast Res., 1: 221224.

Chaffin, W.L., Lopez-Ribot, J.L., Casanova, M., Gozalbo, D., Martinez, J.P. 1998. Cell wall and secreted proteins of Candida albicans: identification, function and expression. Microbiol. Mole. Biol. Rev., 62: 130-80.

Chattopadhyay, S., Kaur, A., Jain, S., Singh, H. 2013. Sensitive detection of foodborne pathogen Salmonella by modified PAN fibers-immunoassay. Bios Bioel., 45: 274-280. doi: 10.1016/j.bios.2013.01.032

Cheng, H.R. and Jiang, N. 2006. Extremely rapid extraction of DNA from bacteria and yeasts. Biotechnol. Lett., 28: 55-59.

Doyle, J.J. and Doyle, J.L. 1987. A rapid DNA isolation procedure for small quantities of fresh leaf tissue. Phytochem Bull., 19: 11-15.

Faggi, E., Pini, G. and Campisi, E. 2005. Use of magnetic beads to extract fungal DNA. Mycoses, 48: 3-7.

Flamm, R.K., Hinrichs, D.K., Thomashow, M.F. 1984a. Introduction of pAM beta1 into Listeria monocytogenes by congugation and homology between native L. monocytogegenes plasmids. $J$. Bacteriol., 159: 214-221.

Flamm, R.K., Hinrichs, D.J., Thomashow, M.F. 1984b. Introduction of pAM beta 1 into Listeria monocytogenes by conjugation and homology between native L. monocytogenes plasmids. Infect. Immun., 44: 157-161.

Fredricks, D.N., Smith, C. and Meier, A. 2005. Comparison of Six DNA
Extraction Methods for Recovery of Fungal DNA as Assessed by Quantitative PCR. J. Clin Microbiol., 43(10): 5122-5128

Gontia-Mishra, I., Tripathi, N. and Tiwari, S. 2014. A simple and rapid DNA extraction protocol for filamentous fungi efficient for molecular studies. Indian J. Biotech., 13: 536-539.

González-Mendoza, D., Argumedo-Delira, R., Morales-Trejo, A., Pulido-Herrera, A., Cervantes-Díaz, L., Grimaldo-Juarez, O. and Alarcón, A. 2010. A rapid method for isolation of total DNA from pathogenic filamentous plant fungi. Genetics and Mol. Res., 9(1): 162-166.

Goodwin, D.C. and Lee, S.B. 1993. Rapid, microwave mini-prep of total genomic DNA from fungi, plants, protists and animals for PCR. Bio Techniques, 15: 438-444.

Griffin, D.W., Kellogg, C.A., Peak, K.K. and Shinn, E.A. 2002. A rapid and efficient assay for extracting DNA from fungi. Lett. Appl. Microbiol., 34: 210-214.

Jaykus, L.A. 2003. Challenges to developing real-time methods to detect pathogens in foods. ASM News, 69: 341-347.

Jia, Y., Wamishe, Y.A. and Zhou, B. 2014. An expedited method for isolation of DNA for PCR from Magnaporthe oryzae stored on filter paper. The Crop J., 2: 267-271.

Kennedy, J. and Marchesi, J.R. 2007. Metagenomic approach to exploit the biotechnological potential of the microbial consortia of marine sponges. Appl. Microbiol. Biotechnol., 75: 11-20.

Kumar, M.S., Kaur, G. and Sandhu, A.K. 2012. Genomic DNA isolation from fungi, algae, plant, bacteria and human blood using CTAB. Int. J. Sci. and Res., 3(9): 617-618.

Lee, S.B., Milgroom, M.G. and Taylor, J.W. 1988. A rapid, high yield mini-prep method for isolation of total genomic 
DNA from fungi. Fungal Genet Newsl., 35: 23-24.

Li, S.L., Zhou, B., Yang, L.Y., Li, Z.Y., Zhang, Q. and Chen, Y.W. 2002. An improved method for extracting fungal DNA. J. Yunnan Univ., 24: 471-472.

Liu, D., Coloe, S., Baird, R. and Pedersen, J. 2000. Rapid Mini-Preparation of Fungal DNA for PCR. J. Clin. Microbiol., 38(1): 471.

Milgroom, M.G. and Fry, W.E. 1997. Contributions of population genetics to plant disease epidemiology and management. Adv. in Bot. Res., 24: 130.

Mot'ková, P. and Vytřasová, J. 2011. Comparison of Methods for Isolating Fungal DNA. Czech J. Food Sci., 29(Special Issue): S76-S85.

Mseddi, F., Jarboui, M.A., Sellami, A. and Ayadi, A. 2011. A rapid and easy method for the DNA extraction from Cryptococcus neoformans. Biol. Procedures, 201113:5 doi: 10.1186/1480-9222-13-5

Muller, F.M., Werner, K.E., Kasai, M., Francesconi, A., Chanock, J. and Walsh, T.J. 1998. A Rapid extraction of genomic DNA from medically important yeasts and filamentous fungi by high-speed cell disruption. J. Clin. Microbiol., 36: 1625-1629.

Naravaneni, R. and Jamil, K. 2005. Rapid detection of food-borne pathogens by using molecular techniques. J. Med. Microbiol., 54: 51-54. doi: 10.1099/jmm.0.45687-0.

Noor Adila, A.K., Farah Diba, A.B., Zamri, Z., Wan Mohtar, W.Y. 2007. Comparison of methods for isolating high quality DNA and RNA from an oleaginous fungus Cunninghamella bainieri strain 2a1. Mal. J. Microbiol., 3: 7-13.

Płaza, G.A., Upchurch, R., Brigmon, R.L., Whitman, W.B. and Ulfig, K. 2004.
Rapid DNA Extraction for Screening Soil Filamentous Fungi Using PCR Amplification. Polish J. Environ Studies, 13(3): 315-318.

Prabha, T.R., Revathi, K., Vinod, M.S., Shanthakumar, S.P. and Bernard, P. 2013. A simple method for total genomic DNA extraction from water moulds. Curr. Sci., 104(3): 345-347.

Purohit, M.K. and Singh, S.P. 2009. Assessment of various methods for extraction of metagenomic DNA from saline habitats of coastal Gujarat (India) to explore molecular diversity. Lett. Appl. Microbiol., 49(3): 338-344.doi: 10.1111/j.1472-765X.2009.02663.x

Saghai-Maroof, M.A., Soliman, K.M., Jorgensen, R.A., Allard, R.W. 1984. Ribosomal DNA spacer-length polymorphisms in barley: Mendelian inheritance, chromosomal location and population dynamics, Proc. Natl. Acad. Sci. U. S. A., 81: 8014-8018.

Sambrook, J., Fritsch, E.F., Maniatis, T. 1989. Molecular cloning: A laboratory manual., 2nd ed. Cold Spring Harbor Laboratory Cold Spring Harbor, NY.

Sambrook, J. and Russel, D.W. 2001. Rapid isolation of yeast DNA. In: Sambrook J, Russell DW (Eds) Molecular Cloning: A Laboratory Manual (2nd Edn), Cold Spring Harbor Laboratory, New York, pp. 631-632.

Sharma, P., Capalash, N. and Kaur, J. 2007. An improved method for single step purification of metagenomic DNA. Mol. Biotechnol., 36: 61-63.

Syn, C.K. and Swarup, S. 2000. A scalable protocol for isolation of large-sized genomic DNA within an hour from several bacteria. Annals of Biochem., 278: 86-90.

Tendulkar, S.R., Gupta, A., and Bharat B. Chattoo 2003. A simple protocol for isolation of fungal DNA. Biotechnol. Lett., 25: 1941-1944. 
Wilson, K. 1990. Preparation of genomic DNA from bacteria. In: Ausubel FM, Brent R (Eds) Current Protocols in Molecular Biology, Greene Publishing Association and Wiley Interscience, New York, pp 241-245.

Wolffs, P., Knutsson, R., Norling, B., Radstrom, P. 2004. Rapid quantification of Yersinia enterocolitica in pork samples by a novel sample preparation method, flotation, prior to real-time PCR. J. Clin. Microbiol., 42:1042-1047. doi: 10.1128/JCM.42.3.1042-1047

Wu, Z.H., Wang, T.H., Huang, W. and Qu, Y.B. 2001. A simplified method for chromosome DNA preparation from filamentous Fungi. Mycosystema, 20: 575-577.

Umesha, S., Manukumar, H.M. and Raghava, S. 2016. A rapid method for isolation of genomic DNA from food-borne fungal pathogens. Biotech., 6(2): 123.

Van Burik, J.A., Schreckhise, R.W., White, T.C., Bowden, R.A. and Myerson, D. 1998. Comparison of six extraction techniques for isolation of DNA from filamentous fungi. Med.Mycol., 36: 299303.

Voget, S., Leggewie, C., Uesbeck, A., Raasch, C., Jaeger, K.E. and Streit,
W.R. 2003. Prospecting for novel biocatalyst in a soil metagenome. Appl. Environ. Microbiol., 7: 6235-6242.

Xue, S.J., Yue, T.L., Guan, J., Yuan, Y.H. and Gao, Z.P. 2006. An improved method for extracting fungal DNA. Food Res. Develop., 27: 39-40.

Zhang, D., Yang, Y., Castlebury, L.A. and Cerniglia, C.E. 1996. A method for the large scale isolation of high transformation efficiency fungal genomic DNA. FEMS Microbiol. Lett., 145: 261-265.

Zhang, M., Zhang, Y., Scheuring, C.F., Wu, C.C., Dong, J.J. and Zhang, H.B. 2012. Preparation of megabase-sized DNA from a variety of organisms using the nuclei method for advanced genomics research. Nature Protocols, 7(3): 467478. doi:10.1038/nprot.2011.455

Zhang, Y.Z., Zhang, S., Liu, X.Z., Wen, H.A. and Wang, M. 2010. A simple method of genomic DNA extraction suitable for analysis of bulk fungal strains. Lett. in Appl. Microbiol., 51: 114-118. doi:10.1111/j.1472765X.2010.02867.x

Zhang, Y.H., Wei, D.S., Xing, L.J. and Li, M.C. 2008. A modified method for isolating DNA from fungus. Microbiol. China, 35: 466-469.

\section{How to cite this article:}

Swapan K. Tripathy, Manasmita Maharana, Dinesh Manohar Ithape, Devraj Lenka, Dayanidhi Mishra, Arjun Prusti, Digbijaya Swain, Mihir Ranjan Mohanty and Reshmi Raj K.R. 2017. Exploring Rapid and Efficient Protocol for Isolation of Fungal DNA. Int.J.Curr.Microbiol.App.Sci. 6(3): 951-960. doi: https://doi.org/10.20546/ijcmas.2017.603.113 